\title{
Human Rights Attitude Scale: A Validity and Reliability Study
}

\author{
Recep Ercan ${ }^{1}$, Tugba Yaman ${ }^{1}$ \\ ${ }^{1}$ Cumhuriyet University Education Faculty Sivas, Turkey \\ Correspondence: Selcuk Besir Demir, Cumhuriyet University Education Faculty Sivas, Turkey
}

Received: August 11, 2015 Accepted: August 28, $2015 \quad$ Online Published: September 18, 2015

doi:10.11114/jets.v3i6.1031 URL: http://dx.doi.org/10.11114/jets.v3i6.1031

\begin{abstract}
The objective of this study is to develop a valid and reliable attitude scale having quality psychometric features that can measure secondary school students' attitudes towards human rights. The study group of the research is comprised by 710 6th, 7th and 8th grade students who study at 4 secondary schools in the centre of Sivas. The study group was chosen from secondary school students through random cluster sampling. In line with the related literature, a trial item pool was formed and expert opinion was sought for by asking help from expert lecturers in the area. Following the pilot study, the draft scale was applied on the study group. Exploratory Factor Analysis (EFA) was used to determine the factor construct and Confirmatory Factor Analysis (CFA) was used to determine construct validity and other validity tests were conducted as well. The data of the study was analyzed through PASW 18.0 ve Lisrel 8.51 multi-task programs in a computer setting. Exploratory and Confirmatory Factor Analyses were made to determine the construct validity of the scale. The correlations of item-test scores and internal coherence coefficient Cronbach Alpha were calculated. T-test was resorted to to find out the distinguishing power of items. Cronbach Alpha reliability coefficient of the sub-items of the scale and the scale as a whole (0.821) and correlation coefficients among subtitles indicate that the scale is reliable.This four factor scale consisting of 21 items is a usable and reliable model because all conformity values are within the range of acceptable limits.
\end{abstract}

Keywords: human rights, human rights education, attitude scale, factor analysis

\section{Introduction}

The human-being is the most valuable thing in the universe thanks to his physical qualities, mind, speech, emotions and the ability to improve himself constantly. There have been periods throughout history in which this value has not been able to be protected and states have formed some protective systems in recent centuries to make human-being attain the value he has deserved. This set of rules gathered under the "Human Rights" concept has turned into an important field both in the national and international context (Human Rights Annual Report, 2013:2).

Human rights are the entire rights all human beings should have as a requirement of humanly honour only because they are human beings, without any discrimination based on language, religion, race, gender, economic or social status (Uygun, 1996:6). The ideas of human rights have been left as an inheritance to our contemporary society as a result of big struggles in various periods of humanity (Hekimoğlu, 2002; Tanırlı, 2007). "Magna Carta" signed in England, "American Declaration of Independence" that took place in 1776, and "Declaration of Human and Civic Rights" as a result of "French Revolution" in 1789 have declared rights that are valid for the whole world (Tanırlı, 2007:1).

Among all the human rights and freedom categories, human rights imply the entire set of rights that protect the individual against the state, other individuals and groups of individuals (Hekimoğlu, 2002:68). Human rights are the rights a person has just because he/she is a human (Blackstone, 1969; Kuçuradi, 1996; Oğuşgil, 2008). According to Blackstone (1969), on no accounts can the individuals be classified based on the rights they have (qtd.in Güdücü, 2008:3). Human rights do not only belong to the strong and powerful (Galtung, 1999:126). These rights are the rights that all human beings should have (Oğuşgil, 2008:1). In short, human rights are the rights related to being a human. Living, being free and equal, having personal security, not being made to work as a slave, travelling freely, getting married and establishing a family, enrolling in elections, owning property, thinking, defending his/her own beliefs, working in good conditions, getting relaxed, being educated and believing in a religion chosen by the individual are among the most essential human rights.

At the very heart of human rights, there are notions such as tolerance, living in peace, respecting others' rights and 
freedom. The essence of the notion "human rights" includes values such as respecting the human being, equality, brotherhood, solidarity, friendship (Oğuşgil, 2008; Tanırlı, 2007). According to Donelly (1995), human rights are needed not for the purpose of life but for leading an honorable life (qtd. in Uyangör, 2007:36). Having human rights is closely associated with human honor (Shue, 1996:26).

Quoting Flowers (2000), human rights are the rights people have innately and due to their existence. They cannot be taken, transferred or lost on any account. They cannot be put into an order of importance. They have dependent and complementary qualities. Thus, human rights have a unity in themselves, implying that none of them can either be surrendered or conceded even slightly.

People can lead their lives as respectable individuals and fulfill themselves so long as they know and recognize these rights and live accordingly. Human rights education is vital for peace, tolerance, compromise and democracy be absorbed in society and for all these turn into a lifestyle (Cunningham, 1991; Karaman-Kepenekçi, 2000; Üste, 2007). Therefore, it is a must that human rights be learnt and known. In democratic societies Educational systems are expected to fulfill this task (Hornberg, 2002; Tanırlı, 2007). Basic education given during primary school affect student behavior through knowledge. Giving value to a person because he/she is a human being arise during primary education along with socialization. Primary education is a basic period in the development of relations among people. It is required that concepts regarding human rights be adopted during primary education in order to bring up young people who have tolerance, ability to compromise and are pacifists. It is important to provide students with "human rights education" in an intense manner particularly during primary education (Torney et al., 1975; Üste, 2007).

Human rights education has an important mission so as to be able to raise and improve human rights consciousness and most importantly to prevent human rights negligences (Gökburun, 2007:92-93). A person needs to be aware of what rights he/she has, know why and how these rights should be protected and also be knowledgeable about attitudes and behavior leading to negligence (Oğuşgil, 2008:2-3).

In the teaching and instruction of Citizenship and Democracy Education course in primary school, the purpose is to introduce some basic concepts to students regarding democracy and human rights as well as to make students acquire awareness, sensibility, consciousness, thought, attitude and behavior regarding the protection and practice of human rights. Therefore, through Citizenship and Democracy Education course instruction programme it is aimed to make the student have positive attitudes towards all elements concerning society, environment, and humanity (Bozbek ve Demir, 2014:1), since attitudes significantly affect behavior. According to Karatekin et al. (2012), human rights education does not only involve cognitive processes but also a set of skills, behaviours and attitudes. Attitude can be defined as the tendency to react to individuals, places, incidents or thoughts either in a negative or positive way (Simpson et al, 1994:212). Attitudes are among the most important affective qualities that have an impact upon learning. Affective qualities increase cognitive achievement roughly a quarter more in the related field and attitudes concerning the field being learnt have an influence on the cognitive achievement (Bloom, 2012). The measurement of attitudes in teaching-learning process is beneficial so as to predict the learner's behavior in future by finding out(saptmk) about his/her attitudes in a certain period of time, change his/her attitudes or form new attitudes and learn the already existent choices of learners. (Nuhoğlu, 2008). Being aware of the attitudes the student has will help the teacher to determine methods and approaches and to arrange the organization of the course (Tosun, 2011:8). As can be understood from here, whether the students' attitudes towards human rights are positive or negative may lead to considerable differences in the level of fulfilling the achievements of the course serving this purpose and cognitive achievement levels. Because of this, students' attitudes towards human rights need to be determined. In order to achieve this end, valid and reliable attitude scales that can measure attitudes and have good psychometric qualities are needed.

When the literature is reviewed concerning the attitude scale developed for human rights, expert opinion was sought for to determine the content validity of "Attitude Scale Concerning Democracy, Citizenship and Human Rights" developed by Acun, İnel ve Yücel (2012) and factor analysis was made and item distinguishing powers were calculated to determine its validity. As a result of the analysis, it was conluded that the scale had a construct that had 11 sub-factors. Blanco et al. (2004) used human rights knowledge scale in their study entitled "Human Rights and Ethnic Attitudes in Spain: The Role of Cognitive, Social Status, and Individual Difference Factors". This scale is a 7-point Likert-type scale consisting of 7 items including the human rights laws and policies of the EU and Spain as a result of the negotiations carried out by the lead author of the study with the members of European Community of Human Rights. The grading on the scale goes from "this is utterly true" to "this is not so much true". The average of the scale is 25.43 ( $\mathrm{SD}=4.97, \alpha$ =94). The scale items involve issues such as factual expressions regarding human rights, civil rights, human knolwdge and minority rights.

“An Attitude Scale Concerning Universal Values" has been developed by Demir and Koç (2009). For this, a five point Likert type scale including 41 items was developed and the prepared scale draft was applied on $4027^{\text {th }}$ grade students 
studying in Ordu in 12 primary schools having students from various socioeconomic backgrounds. The KMO (Kaiser-Meyer-Olkin) value of the scale was found as 0,81 ; Bartlett test value was found as 5311,891 and Cronbach Alpha reliability coefficient was found as 0,86 . The new scale had a total of 41 items, 28 of which were positive and 13 of which were negative. The factor loadings of the items range between 0.35 and 0.65 . According to the obtained data, it was concluded that the scale is valid and reliable. Another scale developed by another author is "Human Rights and Piety Scale". Hans ven der Ven from Radboud University in Holland carried out an international project about human rights and piety and its participants were high school students. A scale including different dimensions of human rights was developed for the project. Of the questions in this scale, 16 aims to measure civil rights under the category of human rights and the scale consist of 6 sub-categories: freedom of life-style, distinction between religion and state and freedom to speak about on religious issues, freedom to speak on moral issues, freedom to hold meetings, freedom of press, freedom of private life and freedom of religion. Each sub-category has been measured through two distinct items. The scale has been arranged as a Likert type scale with five choices. Factor analysis was conducted on the scale and the answers given to the questions on the scale and the students' attitudes towards human rights and piety were analyzed.

In another study, "Attitude Scale Concerning Human Rights Education” was developed by Karaman-Kepenekçi (1999) to measure students' attitudes towards human rights. Validity and reliability studies were conducted while this scale was being developed. In order to test the validity of the scale, content validity and criterion validity were checked. Factor analysis was used within this framework and pearson $r$ was calculated for the criterion validity of the scale. Alpha formula was used for reliability studies. In order to distinguish positive and negative attitudes, the distinguishing power of each item was checked. An attitude scale study concerning child rights which is an important part of human rights was made again by Karaman-Kepenekçi (2006) and as regards the validity and reliability of the scale we have the information that the scale is a one factor scale and the total item correlation coefficients of the items in the scale range between 32 and 61. Pirsl, Stimac ve Pokrajac-Bulian (2007) developed two types of questionnaires for their study entitled "The Attitudes of Students and Teachers Towards Civic Education and Human Rights". The first one of these questionnaires is a 5 point Likert type scale with 11 items. The grading in this scale is from 1 "I completely disagree" towards 5 "I completely agree". This scale involves 4 issues. These issues are related to students' and teachers'; 1) The level of freedom to make decisions in their daily lives in the local society; issues such as family, school/classes and fellow group. 2) The level of expressing their own opinions in the local society; issues such as family, school/classes and fellow group. 3) Their level of activity in their local society concerning issues such as environment, the disabled, the old, the unemployed, caring for young people, accommodation and health caring services.4) Determining their level of motivation for enhancing active participation to the resolution of issues in the local society. In addition to these, a questionnaire that consisted of 6 open ended questions was developed to learn the students' opinions about equality at home, the rights and obligations of citizens, their own obligaitons and rights at home and school. The second questionnaire developed for the study is for teachers. This questionnaire consists of 10 items and aims to learn teachers' opinions about citizenship and human rights education.

One another study is related to developing "An Attitude Scale Concerning Citizenship and Human Rights Education" by Üstündağ (1997). The realiability of the attitude scale was calculated using Cronbach Alfa coefficient and reliability was found as 0.90 . Even though all of the mentioned scales have positive aspects, only exploratory factor analysis was made in order to achieve construct validity; confirmatory factor analysis was not benefited from.Therefore, the goodness of fit index and the fitness of model for the mentioned scales have not been handled. Within this context, the reseracher's aim is to develop a valid and reliable scale attitude that has quality psychometric features and can measure secondary school students' attitudes towards human rights.

\section{Method}

\subsection{Study Group}

The study group of the research is comprised by 710 students who are $6^{\text {th }}, 7$ th and $8^{\text {th }}$ grade secondary school students studying at 4 secondary schools located in the city centre in 2013-2014 education year. The study group has been chosen through random cluster sampling method out of secondary school students. Moreover, equal numbers of girls and boys and $6^{\text {th }}, 7^{\text {th }}$ and $8^{\text {th }}$ grade students were tried to be chosen as much as possible. Of the 764 students having enrolled in the study, 54 students' forms were not taken into account due to either missing parts or choosing more than one choice. Those students who were not taken into account were taken out and the answers of 710 students were assessed. Information concerning the study group has been given on Table 1. 
Table 1.Information Concerning The Study Group

\begin{tabular}{lrrrr}
\hline School & Boys & Girrls & Total & $\%$ \\
\hline Ziya Gökalp Secondary School & 148 & 152 & 300 & 42,3 \\
Başögretmen Atatürk Secondary & 126 & 134 & 260 & 36,6 \\
$\begin{array}{l}\text { School } \\
\text { Mevlana Secondary School }\end{array}$ & 31 & & & \\
Kadı Burhaneddin Secondary School & 35 & 54 & 85 & 11,9 \\
$\quad$ Total & $\mathbf{3 4 0}$ & 30 & 65 & 9,2 \\
\hline
\end{tabular}

\subsection{The Process in which The Scale Concerning Attitude towards Human Rights was Developed}

In order to be able to reach reliable findings within the framework of developing the scale, the number of individuals comprising the study group should be a few times more (at least five) than the number of items in the draft scale (Anderson, 1988:427). The draft scale was applied on a study group of 710 people. The draft scale includes 68 items. Within this context it can be said that students ten times as many as the item numbers have been included in the study group. Human Rights Attitude Scale is a likert type scale that aims to measure affective qualities of students. Grading in attitude scales can be made in 5 point grading that ranges from "I completely agree" to "I completely disagree" (Dunn-Rankin, 2004; Tavşancıl, 2005). In this study, scale grading has been made thus: "I completely disagree: 1", "I disagree: 2", "I am undecided: 3", "I agree: 4" ve "I completely agree: 5. The answers of negative statements defined on the scale have been recoded in the reverse way from "I completely Agree: 1" to "I completely Disagree: 5", from "I Agree: 2" to "I disagree: 4". When the available literature is reviewed, the stages of scale development are as below (Tavşanc11,2005; Dunn-Rankin, 2004; Devellis, 2003; Karasar, 1995).

1. Creation of the Item Pool

2. Seeking For Expert Opinion

3. Conducting the Pilot Study

4. Applying the Scale on the Study Group and Factor Analyses

5. Calculating the Realiability of the Scale

\subsection{The Item Pool}

Firstly, a trial item pool was created within the process of developing Human Rights Scale Attitude (HR-SA) that aims to determine secondary school students' attitudes towards human rights. While the statements regarding the attitudes were being written, an extensive literature review was conducted and attitude scales concerning human rights (Acun et al., (2012); Blanco et al., (2004); Çetintaş and Gömleksiz, (2011); Demir and Koç, (2009); Karaman-Kepenekçi, (1999); Karaman-Kepenekçi, (2006);Pirsl, Stimac and Pokrajac-Bulian, (2007); Üstündağ, (1997)) were analyzed and the items as regards the issue were written thus. While the scale items were being written, a trial version of 85 items was formed as a result of these analyses. In order to balance the "approval" tendencies of the answerers, the scale consists of 85 items, 42 of which are negative and 43 of which are positive. The prepared items were organized so as to express desirable and undesirable situations, not factual ones.

\subsection{Seeking For Expert Opinion}

Two speacialist lecturers in the field of Social Sciences Education were requested to criticize the items in the trial item pool within the context of the content of the human rights concept, the objective of the study, student level and they were also asked to add to and omit from the items if necessary. In order to get expert opinion, the items were classiffied into three and the experts were asked to grade the items as "suitable", "partially suitable" and "unsuitable". The items graded as "unsuitable" were omitted from the trial item pool and the ones graded as "partially suitable" were rearranged within the context of the stated opinions.

While some of the items were rearranged within the context of the feedback by related experts, 5 items were taken out from the trial item pool. Then, social sciences teachers were asked to assess the items in terms of content and suitability to student level. 4 items were taken out as a result of feedback given by teachers. All the written items were assessed in terms of language, meaning and manner of expression. Following these assessments, the required arrangements were made on the items concerning spelling, punctuation, language, meaning and manner of expression. 5 items were taken out because they were regarded to have problems in terms of language and manner of expression.

Following all these stages, the trial item pool was assessed by a lecturer who is experienced in developing scales and has a postgraduate degree in the Measurement-Assessment field. In the whole process described above, the items were assessed according to whether they are attitude statements or not, the way they are expressed, their suitability to the objective of the study and content validity. Because three items were found as inadequate to measure attitudes, these items were taken out from the item pool.

To sum up, 5 items were taken out as a result of feedback by two lecturers about the content and the objective of the 
study; 4 items were taken out as result of the feedback by social sciences teacher about the content and suitability to student level; 5 items were taken out because they were seen to have problems in terms of language and manner of expression and 3 items were taken out because the lecturer specialist in the Measurement-Assessment field stated that these items were unable to measure attitudes. Therefore, 17 items were excluded from the trial item pool that consisted of 85 items.

\subsection{The Process of Pilot Study Period}

There are 68 items in the trial item pool that acquired its final form before the pilot study. The items being put into a random order, the pilot study of the prepared scale draft was conducted on 184 student studying at $6^{\text {th }}, 7^{\text {th }}$ and $8^{\text {th }}$ grades of Selçuk Secondary School and Atatürk Secondary School in the province of Sivas. The 184 student having enrolled in the pilot study of the scale were not included in the study group. After completing the pilot study, the draft filled in by 184 students were processed through PASW 18 program and basic descriptive and inferential statistical analyses were conducted on the items.

The researchers were in the classroom as non-participant observers during the pilot study process and gathered field notes. During these observations, no questions were asked regarding attitude statements in the draft scale and there was no confusion. Following expert opinions and the pilot study process, the draft consisting of 68 items were applied on the study group consisting of $7106^{\text {th }}, 7^{\text {th }}$ and $8^{\text {th }}$ grade students studying in Sivas.

\subsection{Gathering Data}

The data for this study was gathered in May and June in 2014. The objective of the study was explained to the study group and the trial form was applied with the participation of teachers in the classroom setting when the scale was being applied. Within the framework of the permission dated 30/04/2014 and numbered 92255297/605.01/1733168 given by Sivas Office of National Education, both the study group and the school's stakeholders were informed about the facts that the data would be assessed not personally but as a whole, the study did not aim to determine any states or incidents regarding the school and the questions did not have right or wrong answers. They were also informed that the obtained data would be kept confidential and would not be shared by anyone and students were asked to put crosses suitably according to how they see or define themselves. The process of putting crosses were briefly told without being manipulated.

\subsection{Data Analysis}

In this study, Exploratory Factor Analysis (EFA) and Confirmatory Factor Analysis (CFA) were conducted regarding the construct validity of HR-AS. Item-test correlations and internal consistency coefficient were calculated through Cronbach Alfa. The data of the study was analyzed in a computer setting using PASW 18.0 and Lisrel 8.51 multitask programs. Before the required analyses were carried out on the data, negative items were reversed.

Before the Exploratory Factor Analysis, item-test correlations of the trial form that consisted of 68 items were calculated and it was found that there were no items whose item-test correlation coefficient was below 0.40 . In the last stage before the application of Exploratory Factor Analysis, Kaiser-Meyer-Olkin (KMO) test was applied to determine the suitability of sample size to factoring. KMO value was found to be 0.89 as a result of the analysis. Within the context of this finding, it was concluded that sample size was well enough to conduct factor analysis (Brownlow, 2004; Pett, Lackey \& Sullivan, 2003). In addition, when the Bartlett's Test of Sphericity results were examined, it was found out that chi-square value was significant $(\mathrm{X} 2(210)=3816.005 ; \mathrm{p}<.01)$. In the light of all these results, it was accepted that the data could be turned into factors (Child, 2006; Hutcheson \& Sofroniou, 1999; Pett, Lackey \& Sullivan, 2003).

\section{Results}

\subsection{Exploratory Factor Analysis of HR-AS}

In order to determine the factor construct of HR-AS, varimax technique which is one of the vertical rotation methods was chosen by taking into consideration the analysis of essential components as a method of factoring and issues of clarity and meaningfulness (Brownlow, 2004; Walkey \& Welch, 2010). In Exploratory Factor Analysis, sub-cut-point was determined as 0.40 for factor loading and 37 items $\left(1^{\text {st }}, 2^{\text {nd }}, 3^{\text {rd }}, 4^{\text {th }}, 6^{\text {th }}, 7^{\text {th }}, 8^{\text {th }}, 9^{\text {th }}, 10^{\text {th }}, 11^{\text {th }}, 12^{\text {th }}, 13^{\text {th }}, 15^{\text {th }}, 16^{\text {th }}\right.$, $17^{\text {th }}, 18^{\text {th }}, 20^{\text {th }}, 21^{\text {st }}, 24^{\text {th }}, 25^{\text {th }}, 26^{\text {th }}, 31^{\text {st }}, 33^{\text {rd }}, 34^{\text {th }}, 40^{\text {th }}, 41^{\text {st }}, 45^{\text {th }}, 46^{\text {th }}, 50^{\text {th }}, 52^{\text {nd }}, 53^{\text {rd }}, 56^{\text {th }}, 57^{\text {th }}, 58^{\text {th }}, 59^{\text {th }}, 63^{\text {rd }}$ and $66^{\text {th }}$ ) that remained below this value after repeating the factor analyses a few times were excluded.

When factor loadings were examined, it was seen that 10 items $\left(5^{\text {th }}, 19^{\text {th }}, 28^{\text {th }}, 35^{\text {th }}, 37^{\text {th }}, 38^{\text {th }}, 43^{\text {rd }}, 48^{\text {th }}, 55^{\text {th }}\right.$ and $\left.62^{\text {nd }}\right)$ gave several factors high loadings and the difference between these factor loadings was less than 0.10 . Because these items were considered to be overlapping, they were taken out from the scale. In conclusion, because 10 items were considered to be overlapping and the factor loading of 37 items was below 0.40 , they were taken out from the scale. The scale which consisted of 68 items at the very beginning of the process fell down to 21 items after all these exclusions. 
Factor analysis was re-applied to the scale which fell down to 21 items after the items were taken out. According to the results of Exploratory Factor Analysis, there are 4 factors whose eigen values are greater than 1 . It was seen that the first, second, third and fourth factors contributed at a ratio of $17.734 \%, 11.121 \%, 10.865 \%$ and $9.304 \%$ respectively to the common variance. The contribution made by the four factors to the total variance is $\% 49.024$. This ratio is enough for multi-factor designs (Brownlow, 2004; Fabrigar \& Wegener, 2011; Hutcheson \& Sofroniou, 1999). The factor designs obtained as a result of the analysis and factor loadings of items are given on Table 2.

Table 2. Factor Construct of HR-AS According to EFA

\begin{tabular}{|c|c|c|c|c|c|c|c|}
\hline \multicolumn{2}{|c|}{$\begin{array}{l}\text { Equality and Fundamental } \\
\text { Rights }\end{array}$} & \multicolumn{2}{|c|}{ Respect for Individual Rights } & \multicolumn{2}{|c|}{ Respect for Right to Live } & \multicolumn{2}{|c|}{ Political Rights } \\
\hline Item & $\begin{array}{l}\text { Factor } \\
\text { Loading }\end{array}$ & Item & Factor Loading & Item & $\begin{array}{l}\text { Factor } \\
\text { Loading }\end{array}$ & Item & $\begin{array}{l}\text { Factor } \\
\text { Loading }\end{array}$ \\
\hline 67 & 0.679 & 36 & 0.767 & 54 & 0.766 & 23 & 0.763 \\
\hline 65 & 0.657 & 44 & 0.731 & 30 & 0.758 & 22 & 0.705 \\
\hline 61 & 0.637 & 32 & 0.695 & 14 & 0.700 & 27 & 0.653 \\
\hline 60 & 0.624 & 29 & 0.510 & 39 & 0.691 & & \\
\hline 51 & 0.582 & & & & & & \\
\hline 49 & 0.558 & & & & & & \\
\hline 64 & 0.553 & & & & & & \\
\hline 47 & 0.548 & & & & & & \\
\hline 68 & 0.537 & & & & & & \\
\hline 42 & 0.473 & & & & & & \\
\hline & 734 & & 1.121 & & & & \\
\hline
\end{tabular}

When Table -2 is examined, it is seen that the factor loadings of 10 items below Equality and Fundamental Rights Dimension factor range between 0.679 ile 0.473 , the factor loadings of 4 items below Respect for Individual Rights dimension factor range between 0.767 and 0.510 , the factor loadings of 4 items below Respect for Right to Live Dimension Factor range between 0.766 and 0.691 and the factor loadings of 3 items below Political Rights Dimension Factor range between 0.763 and 0.653 .

\subsection{Item-Total Correlations}

Item-test correlation values that express the validity coefficient of each item are given on Table 3.

Table 3.Item-Test Correlation Values of HR-SA

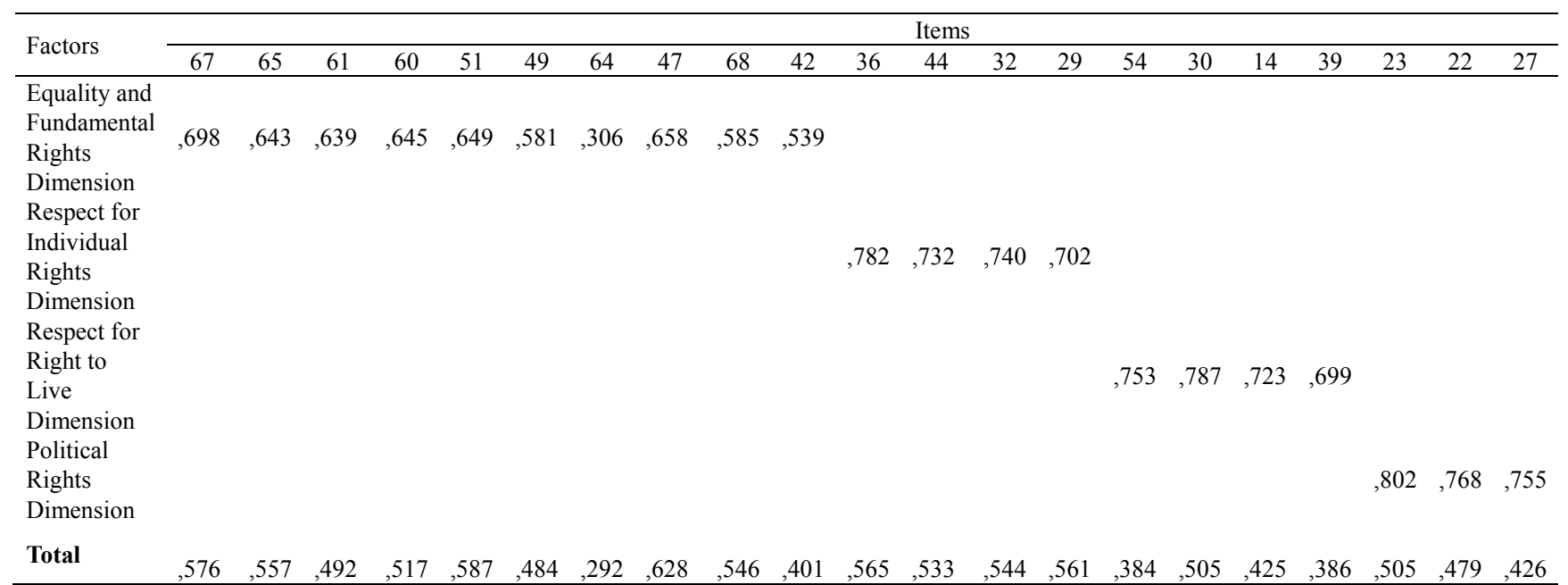

It is seen that the correlation coefficients of items on Table 3 range between 0.802 and 0.306 .

Table 4. Correlations Between the Factor Scores of HR-AS

\begin{tabular}{|c|c|c|c|c|}
\hline \multirow[t]{2}{*}{ Factors } & Equality and Fundamental & Respect for Individual & \multirow{2}{*}{$\begin{array}{l}\text { Respect for Right to } \\
\text { Live Dimension }\end{array}$} & \multirow{2}{*}{$\begin{array}{c}\text { Political Rights } \\
\text { Dimension }\end{array}$} \\
\hline & Dimension & Dimension & & \\
\hline Equality and Fundamental & 1 &, $484 * *$ &, $170 * *$ & ,471** \\
\hline Respect for Individual & $484 * *$ & 1 &, $291 * *$ &, $451 * *$ \\
\hline $\begin{array}{l}\text { Rights Dimension } \\
\text { Respect for Right to Live } \\
\text { Dimension }\end{array}$ &, $170 * *$ &, $291 * *$ & 1 &, $165 * *$ \\
\hline Political Rights Dimension &, $471 * *$ &, $451 * *$ &, $165 * *$ & 1 \\
\hline Total & 0.840 & 0.574 & 0.747 & 0.606 \\
\hline
\end{tabular}


When Table-4 is examined, it is seen that there are meaningful correlations between Equality and Fundamental Rights Dimension and Respect for Individual Rights Dimension at a rate of (0.484), between Equality and Fundamental Rights Dimension and Respect for Right to Live Dimension at a rate of $(0.170)$, between Equality and Fundamental Rights Dimension and Political Rights Dimension at a rate of (0.471), between Respect for Individual Rights Dimension and Respect for Right to Live Dimension at a rate of (0.291), between Respect for Individual Rights Dimension and Political Rights at a rate of (0.451) and between Respect for Right to Live Dimension and Political Rights Dimension at a rate of (0.165).

\subsection{The Distinguishing Features of Items}

T-test was resorted to to determine the distinguishing powers of items in the scale. With this in mind, the total scores obtained from the scale were ordered from big to small and high-low $27 \%$ groups were determined.Independent groups' t-test values were calculated based on the scores of both groups. There is meaningful differentiation between the high and low groups on the scale $(\mathrm{p}<.01)$. This significant finding is an indicator that all the items on the scale have a distinguishing feature at the desired level (Brownlow, 2004).

\subsection{Confirmatory Factor Analysis(CFA)}

In order to assses the validity of four-factor structure that emerged as a result of the Exploratory Factor Analysis of HR-AS, Confirmatory Factor Analysis (CFA) was conducted. The findings obtained as a result of Confirmatory Factor Analysis are given on Table-5 and Figure 1.

Table 5. CFA Result of HR-AS

\begin{tabular}{lc}
\hline Fit Criteria & HR-AS Values \\
\hline$X^{2}$ & 183 \\
p- Value & 0,001 \\
RMSEA (Root Mean Square Error of Approximation) & 0.095 \\
NFI (Normed Fit Index) & 0.89 \\
NNFI (Non-Normed Fit Index) & 0.89 \\
RMR (Root Mean Square Residual) & 0.16 \\
GFI (Goodness of Fit Index) & 0.85 \\
AGFI (Adjusted Goodness of Fit Index) & 0.81 \\
CFI (Comparative Fit Index) & 0.90 \\
RFI (Relative Fit Index) & 0.87 \\
IFI (Incremental Fit Index) & 0.90 \\
PGFI (Parsimony Goodness of Fit Index) & 0.67 \\
PNFI (Parsimony Normed Fit Index) & 0.77 \\
\hline
\end{tabular}

When the fitness values given above are analyzed, it is understood that because RMSEA, GFI, AGFI, CFI are 0.095, $0.85,0.81,0.90$ respectively, they have acceptable fitness values. The other fitness values are either good, perfect or within an acceptable range (Bartholomew, Knott \& Moustaki, 2011; Brown, 2006; Thompson, 2004). 


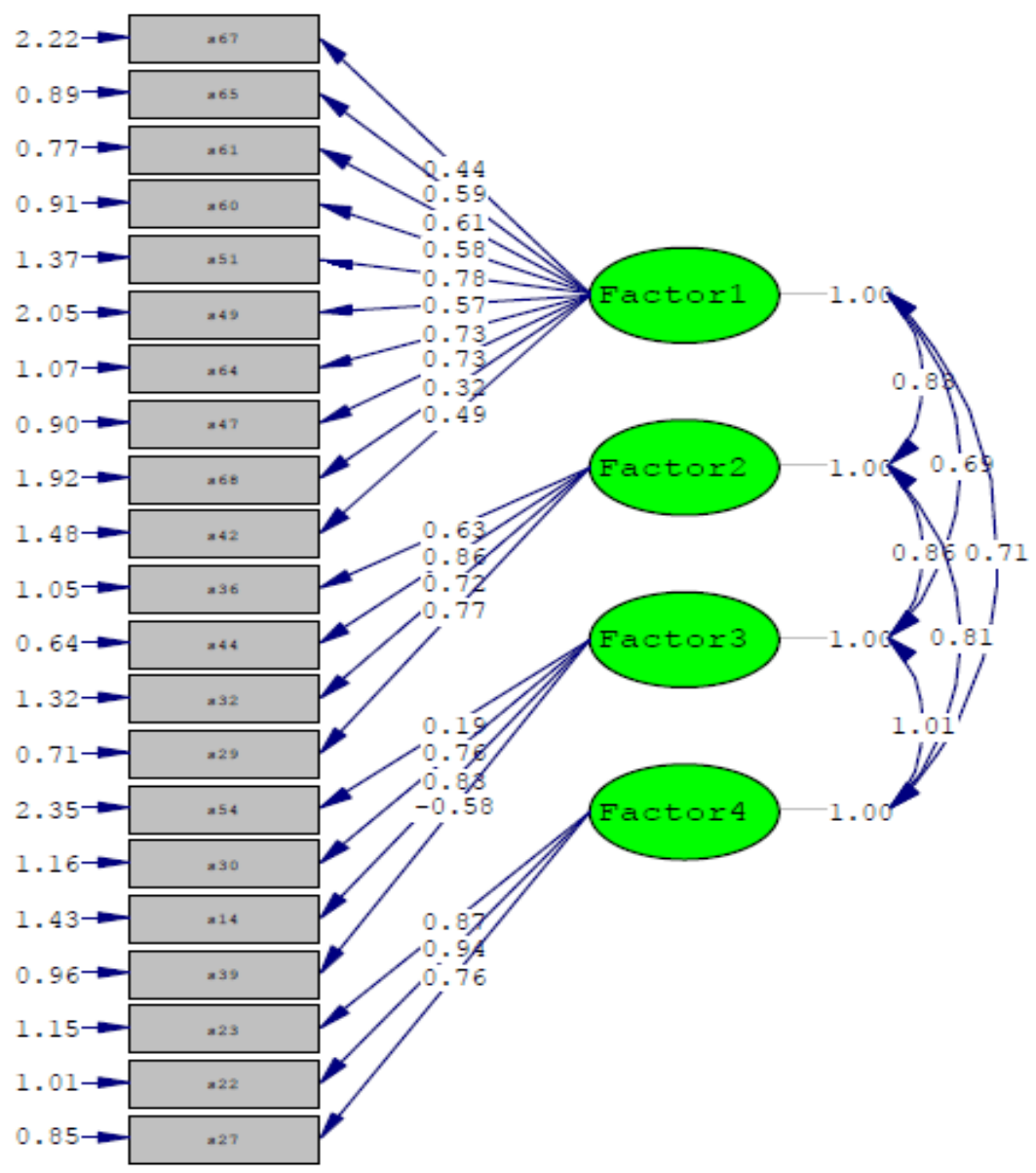

Figure 1. Confirmatory Factor Analysis of HR-AS (Path Diagram)

\subsection{Findings Concerning Internal Consistency}

In order to find out the reliability coefficient of scores obtained from HR-AS, Cronbach Alfa reliability analysis was done. Cronbach Alfa reliability coefficient was calculated as ,821 for the entire scale. Cronbach Alfa reliability coefficients of the sub-factors Equality and Fundamental Rights Dimension, Respect for Individual Rights Dimension, Respect for Right to Live Dimension, Political Rights Dimension were calculated as ,733; , 718; , 726; ,666 respectively. These findings are an evidence that sub-scales are reliable (Brownlow, 2004).

\section{Discussion and Conclusion}

Setting out from the need in the related literature, a valid and reliable attitude scale was aimed to be developed that could determine secondary school students' attitudes towards human rights and and the factors that are effective on these attitudes. Within the framework of developing scales as defined by (Devellis, 2003; Dunn-Rankin, 2004; Karasar, 1995; Tavşancıl, 2005) in the related literature; an item pool was formed, expert opinion was sought for regarding the items and the pilot study stage was fulfilled on the trial item pool.

Following the pilot study, the draft scale was applied on the study group and the distribution of scale scores were analyzed before the Exploratory Factor Analysis was done. After it was determined that the distribution was at the desired level, varimax technique which is one of the vertical rotation techniques was used in order to determine the factor construct of the scale taking into consideration the main constituents analysis as a factoring method, and the aspects of clarity and meaningfulness Exploratory Factor Analysis was conducted on the data a few times both in a sequenced and staged manner. As a result, 10 items were excluded from the scale because they were considered to be overlapping and 37 items were taken out from the scale because their factor loading values were below 0.40 . The scale that initially consisted of 68 items fell down to 21 items after all these omissions were made.

Factor analysis was re-conducted on the the scale which finally consisted of 21 items. According to the results of Exploratory Factor Analysis, there are 4 factors whose eigen values are greater than 1. It was seen that the first factor (Equality and Fundamental Rights Dimension) contributedat a rate of $17.734 \%$; the second factor (Respect for Individual Rights Dimension) contributed at a rate of $11.121 \%$, the third factor (Respect for Right to Live Dimension) 
contributed at a rate of $10.865 \%$; and the fourth factor (Political Rights Dimension) contributed at a rate of $9.304 \%$ to the common variance. The contribution by these 4 factors made to the total variance is 49.024 . The factor loadings of 10 items under the category of Equality and Fundamental Rights Dimension range between 0.679 and 0.473; the factor loadings of 4 items under the category of Respect for Individual Rights Dimension range between 0.767 and 0.510; the factor loadings of 4 items under the category of Respect for Right to Live Dimension range between 0.766 and 0.691 and the factor loadings of 3 items under the category of Political Rights Dimension range between 0.763 and 0.653 .

It has been determined that there is a significant differentiation between high and low groups for each item in the scale and they have a distinguishing quality at the desired level. In order to assess the validity of 4 factor structure that emerged as a result of Exploratory Analysis of HR-AS, Confirmatory Factor Analysis (CFA) was made.

When CFA Fitness values are examined, it has been determined that all goodness of fit indexes are above acceptable ranges. These results indicate that the the scale comply with actual data. It has been concluded that the 4 factor structure of HR-AS is a usable and valid model. Cronbach Alfa reliability analysis was made in order to determine the reliability coefficient of scores obtained from HR-AS'. Cronbach Alpha reliability coefficient was was calculated as ,821 for the entire scale. The Cronbach Alfa reliability coefficients of sub factors which were Equality and Fundamental Rights Dimension, Respect for Individual Rights, Respect for Right to Live, and Political Rights were ,733; ,718; ,726 and ,666 respectively. It has been conluded that the entire scale and its sub-factors are reliable. Because Human Rights Attitude Scale is a valid and reliable attitude scale that can be used to determine secondary school students' attitudes towards human rights and the factors effective on this in experimental and descriptive studies, it can be used as a means of gathering data in studies to be carried out for purposes mentioned above.

\section{References}

Acun, İ., İnel, Y. ve., \& Yücel, C. (2012). Demokrasi, vatandaşlık ve insan haklarına yönelik tutum ölçeği geliştirme. Uluslararası Sosyal Bilgiler Eğitimi Sempozyumu, 20-22 Nisan 2012. İstanbul.

American Psychological Association. (1972). Ethical standards of psychologists. Washington, DC: American Psychological Association.

Anderson, C. A., Gentile, D. A., \& Buckley, K. E. (2007). Violent video game effects on children and adolescents: Theory, research and public policy. http://dx.doi.org/10.1093/acprof:oso/9780195309836.001.0001

Anderson, L. M. (1988). "Likert Scales" Educational research methodology and measurement. An international handbook. New York: Pergoman Press.

Bartholomew, D. J., Knott, M., \& Moustaki, I, (2011) Latent variable models and factor analysis: A unified approach. West Sussex: Wiley. http://dx.doi.org/10.1002/9781119970583

Beck, C. A. J., \& Sales, B. D. (2001). Family mediation: Facts, myths, and future prospects. Washington, DC: American Psychological Association. http://dx.doi.org/10.1037/10401-000

Bernstein, T. M. (1965). The careful writer: A modern guide to English usage (2nd ed.). New York, NY: Atheneum.

Bjork, R. A. (1989). Retrieval inhibition as an adaptive mechanism in human memory. In H. L. Roediger III, \& F. I. M. Craik (Eds.), Varieties of memory \& consciousness (pp. 309-330). Hillsdale, NJ: Erlbaum.

Blackstone, W. T. (1969). Human rights, equality and education, education and ethics. (Edit. W. T. Blackstone and G. L. Newsome). Athens: University of Georgia Press .

Blanco, A., Dunbar, E., Sullaway, M., \& Horcajo, J. (2004). Human rights and ethnic attitudes in Spain: The role of cognitive, social status, and individual difference factors. International Journal of Psychology, 39(2), 106-117. http://dx.doi.org/10.1080/00207590344000196

Bloom, B. S. (2012). İnsan nitelikleri ve okulda öğrenme.(Çev: D. A. Özçelik). Ankara: Pegem Akademi Yayınları.

Bozbek, M., \& Demir, S. B.

(2014).Vatandaşlık ve demokrasi eğitimi dersine yönelik tutum ölçeği; Geçerlik ve güvenirlik çalışması.

Dicle Üniversitesi Ziya Gökalp Eğitim Fakültesi Dergisi, 23, 323-351.

Brown, T. A. (2006). Confirmatory factor analysis for applied research. New York: Guilford Pres.

Brownlow, C. (2004). SPSS explained. London: Routledge.

Child, D. (2006). The essentials of factor analysis. London: Continuum International Publishing Group.

Cress, C. M. (2009). Curricular strategies for student success and engaged learning [PowerPoint slides]. http://www.vtcampuscompact.org/2009/TCL_post/presenter_powerpoints/Christine\%20Cress\%20-\%20Curricular $\% 20$ Strategies.ppt 
Cunningham, J. (1993). The human rights secondry school. (Ed. H.Starkey). The Challenge of Human Rights Education. London.

Demir, S. B., \& Koç, K. (2009). Evrensel değerlere ilişkin bir tutum ölçeğinin geçerlik ve güvenirliği. I. Uluslararası Avrupa Birliği, Demokrasi, Vatandaşllk ve Vatandaşlık Eğitimi Sempozyumu, 28-30 Mayıs 2009. Uşak

Devellis, R. (2003). Scale Development Theoryand Applications. London: SAGE.

Donelly, J. (1995). Teoride ve uygulamada evrensel insan hakları. (Çev. M. Erdoğan ve L. Korkut). Ankara: Yetkin Yayınları.

Driedger, S. D. (1998). After divorce. Maclean's, 111(16), 38-43.

Dunn, R. P. (2004). Scaling Methods. London: Routledge.

Emniyet Genel Müdürlü̆g̈̈ 2012 Yllı İnsan Haklarl Faaliyet Raporu, (2013), Ankara.

Fabrigar, L. R., \& Wegener. D. T. (2011). Exploratory factor analysis. Oxford: Oxford University Pres. http://dx.doi.org/10.1093/acprof:osobl/9780199734177.001.0001

Flowers, N. (2000). The human rights education handbook: effective practices for learning,action and change. Minneapolis: The HumanRights Resource Center.

Galtung, J. (1999). Bir başka açıdan insan hakları. (Ter. Müge Sözen). İstanbul: Metis Yayınları.

Gibbs, J. T., \& Huang, L. N. (1991). Children of color: Psychological interventions with minority youth. San Francisco, CA: Jossey-Bass.

Gilbert, D. G., McClernon, J. F., Rabinovich, N. E., Sugai, C., Plath, L. C., Asgaard, G., \& Botros, N. (2004). Effects of quitting smoking on EEG activation and attention last for more than 31 days and are more severe with stress, dependence, DRD2 A 1 allele, and depressive traits. Nicotine and Tobacco Research, 6, 249-267. http://dx.doi.org/10.1 080/1462220041 0001676305

Gökburun, İ. (2007). Türkiye'de insan hakları düşüncesinin tarihsel gelişimi ve ilköğretim ders kitaplarına yansıması. Yayınlanmamış yüksek lisans tezi, Afyon Kocatepe Üniversitesi, Afyon.

Goleman, D. (2009). What makes a leader? In D. Demers (Ed.), AHSC 230: Interpersonal communication and relationships (pp. 47-56). Montreal, Canada: Concordia University Bookstore. Harvard Business Review, 76(6), 93-102, 1998.

Güdücü-Sezer, H. (2008). İlköğretim programlarında yer alan vatandaşlık ve insan hakları eğitimi dersine ilişkin ögretmen algısına yönelik Manisa örneği. Yayınlanmamış yüksek lisans tezi, Celal Bayar Üniversitesi, Manisa.

Guignon, C. B. (1998). Existentialism. In E. Craig (Ed.), Routledge encyclopedia of philosophy, 3, 493-502. London, England: Routledge.

Hekimoğlu, M. M. (2002). 1982 anayasasına göre insan hakları kavramı. Balıkesir Üniversitesi Sosyal Bilimler Enstitüsü Dergisi, 5(7), 53-70.

Hornberg, S. (2002). Human rights education as an integral part of general education. International Review of Education, 48(3-4), 187-198. http://dx.doi.org/10.1023/A:1020330131832

Hutcheson, G. D., \& Sofroniou, N. (1999). The Multivariate social scientist: introductory statistics using generalized linear models. Thousand Oaks, CA: Sage

Kaçuradi, İ. (1996). Insan haklarının felsefi temelleri.Türkiye Felsefe Kurumu. Ankara.

Karaman, K. Y. (1999). İnsan hakları eğitimine yönelik bir tutum ölçeği. Eğitim Araştırmaları, 51-58.

Karaman, K. Y. (2000). İnsan hakları eğitimi. Ankara: Anı Yayıncılık.

Karaman, K. Y. (2006). A study of university students' attitudes towards children's rights in Turkey. The International Journal of Children's Rights, (14), 307-319. http://dx.doi.org/10.1163/157181806778458095

Karasar, N. (1995). Bilimsel araştırma yöntemi, kavramlar, ilkeler, Ankara: 3A Araştırma Eğitim Danışmanlık Ltd.

Karatekin, N., Kuş, Z., Merey, Z., \& Sönmez, Ö. F. (2012). Sosyal bilgiler öğretmen adaylarının insan hakları eğitimine yönelik tutumları. Turkish Studies, 7(4), 2193-2207.

Kılıçgün, Y. M., \& Oktay, A. (2011). Çocuk haklarına yönelik ebeveyn tutum ölçeğinin geliştirilmesi ve standardizasyonu. Buca Ĕ̈itim Fakültesi Dergisi, 31, 1-22.

Klimoski, R., \& Palmer, S. (1993). The ADA and the hiring process in organizations. Consulting Psychology Journal: Practice and Research, 45(2), 10-36. http://dx.doi.org/10.1037/1061-4087.45.2.10 
Kubrick, S. (Director). (1980). The Shining [Motion picture]. United States: Warner Brothers.

Lebow, D. (1993). Conctructivist values of system design: five principles toward a new mindset. Educational Technology Research and Development, (41), 4-16. http://dx.doi.org/10.1007/BF02297354

MacIntyre, L. (Reporter). (2002). Scandal of the Century [Television series episode]. In H. Cashore (Producer), The fifth estate. Toronto, Canada: Canadian Broadcasting Corporation.

McLuhan, M. (1970a). Culture is our business. New York, NY: McGraw-Hill.

McLuhan, M. (1970b). From cliche to archetype. New York, NY: Viking Press.

Mellers, B. A. (2000). Choice and the relative pleasure of consequences. Psychological Bulletin, 126, 910-924. http://dx.doi.org/10.1037/0033-2909.126.6.910

Nuhoğlu, H. (2008). İlköğretim fen ve teknoloji dersine yönelik bir tutum ölçeğinin geliştirilmesi. İlköğretim Online, $7(3), 627-638$.

Oğuşgil, A. (2008). Bir Avrupa Birliği değeri olarak ilköğretim okullarında insan hakları eğitimi. Yayınlanmamış doktora tezi, İstanbul Üniversitesi, İstanbul.

Pett, M. A., Lackey, N. R., \& Sullivan, J. J. (2003). Making sense of factor analysis: The use of factor analysis for instrument development in health care research. Thousand Oaks, CA: Sage.

Pirsl, E., Stimac, O. M., \& Pokrajac, B. A. (2007). The attitudes of students and teachers towards civic education and human rights. Metodički Obzori, 2, 19-34.

Postman, N. (1979). Teaching as a conserving activity. New York, NY: Delacorte Press.

Postman, N. (1985). Amusing ourselves to death: Public discourse in the age of show business. New York, NY: Viking.

Savery, J. R., \& Duffy, T. M. (1995). Problem Based Learning: An Instructional Model and İts Constructivist Framework. Educational Technology, Sebtember-October, 31-38.

Scheurman, G. (1998). From Behaviorist To Constructivist Teaching. Social Education, 62(1), 6-9

Semenak, S. (1995, December 28). Feeling right at home: Government residence eschews traditional rules. Montreal Gazette, p. A4.

Shue, H. (1996). Temel hakların evrenselliği. Türkiye Felsefe Kurumu. Ankara.

Simpson, R. D., Koballa Jr, T.R., Oliver, J. S., \& Crawley, F. E. (1994). Research on affective dimention of science learning. In D.L. Gabel (Ed.), Handbook of research in science teaching and learning. National Science Teacher Association. NY: Macmillan Publishing Company.

Smerdon, B. A., \& Burkam, D. T. (1999). Access To Constructivist and Didactic Teaching: Who Gets İt? Where İs İt Practised ? Teachers College Record, 99(101), 5-35. http://dx.doi.org/10.1111/0161-4681.00027

Tanırlı, H. (2007). Demokrasi ve insan hakları eğitimi ile ilgili konuların ilköğretim kurumlarında okutulmakta olan ders kitapları içerisindeki yerinin incelenmesi. Yayınlanmamış yüksek lisans tezi, Sütçü İmam Üniversitesi, Kahramanmaraş.

Tavşancıl, E. (2005). Tutumların ölçülmesi ve spss ile veri analizi. Ankara: Nobel Yayınları.

Thompson, B. (2004). Exploratory and confirmatory factor analysis. Washington, DC: American Psychological Association Pres

Torney, J. V., Oppenheim, A. N., \& Farnen, R. F. (1975). Civic education in ten countries: An empirical study. Halstead.

Tosun, Z. D. (2011).Biyoloji dersine yönelik tutum ölçeği geliştirilmesi.Doktora tezi, Gazi Üniversitesi, Ankara.

Üste, R. B. (2007). İnsan hakları eğitimi ve ilköğretimdeki önemi. Ege Akademik BaklşDergisi, 7( 1), 295-310.

Üstündağ, T. (1997). Vatandaşlık ve insan hakları eğitimi dersinin ögretiminde yaratıcı dramanın erişiye ve derse yönelik ögrenci tutumlarına etkisi. Doktora tezi, Hacettepe Üniversitesi, Ankara.

Uyangör, N. (2007). İlköğretim 7. sinıf vatandaşlık ve insan hakları eğitimi programının Değerlendirilmesi. Yayınlanmamış doktora tezi, Hacettepe Üniversitesi, Ankara.

Uygun, O. (1996). Türkiye'de demokrasi ve insan hakları. İnsan Hakları Araştırma ve Derleme Merkezi. Ankara: TODAİE Yayınları.

Walkey, F., \& Welch, G. (2010). Demystifying factor analysis: How it works and how to use it. Bloomington: Xlibris, Corp. 
Appendix A: Human Rights Attitude Scale(HR-AS)

Dear Student;
After reading each statement, choose the one that you think is closest to your
emotions and thoughts.
None of the statements below have precise answers. This is not an exam. Do not
write your names, telephone numbers or the names of your schools. After reading
each statement, please put a cross (X) for the option that first comes to your mind.
Read each statement from beginning to end. Then, choose only one of the options
that go as ; I completely agree, I agree, I am undecided, I disagree, I completely
disagree. Now read each statement in order and choose the option that is most
suitable according to your emotions ...

suitable according to your emotions ...

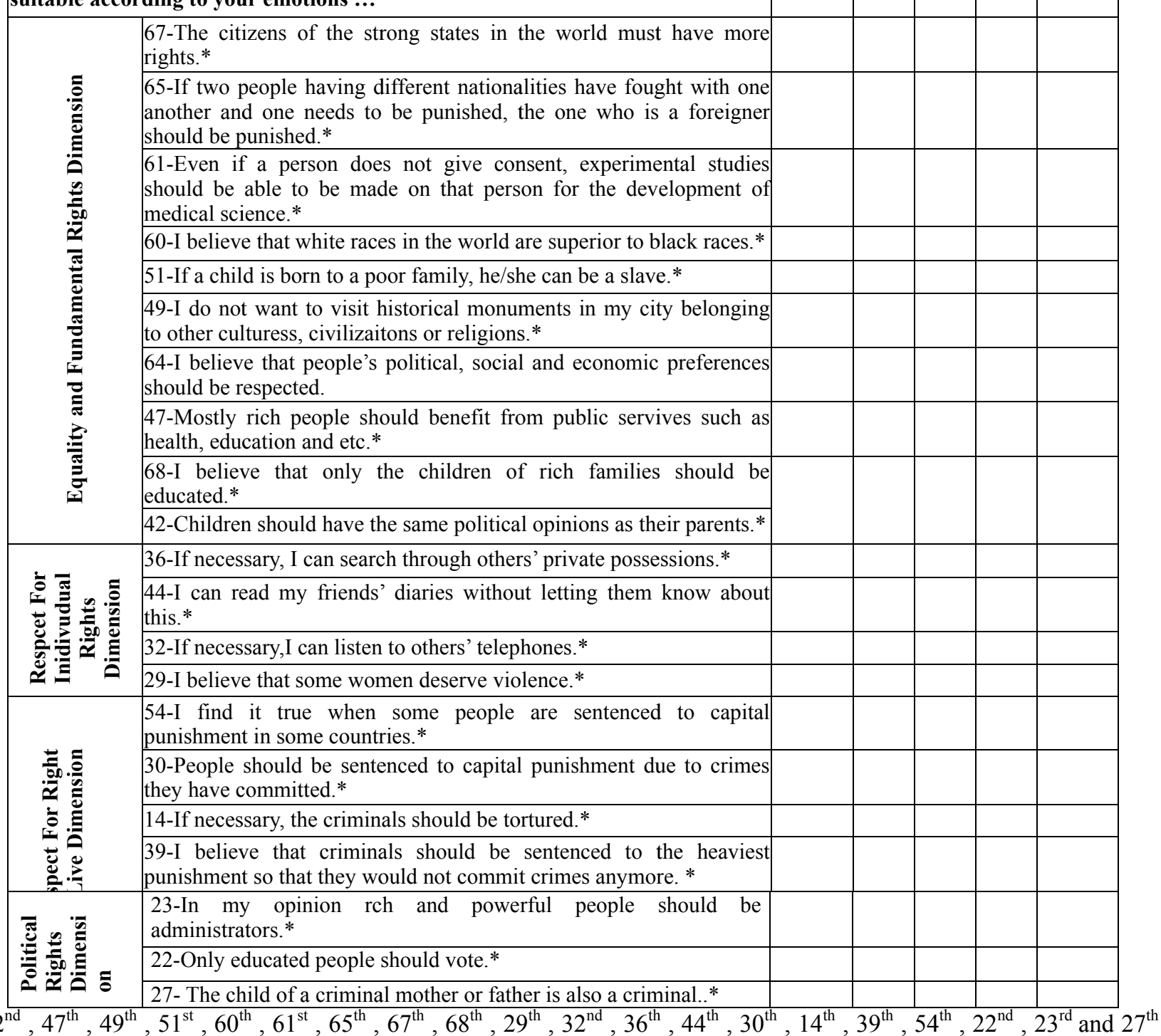
items attitude statements involving a negative meaning.

** Items having a negative meaning should be analyzed after being recoded.

*** While the scale is being used by the researchers, "*" sign located at the end of negative items should be omitted.

\section{$(\mathrm{cc}) \mathrm{Br}$}

This work is licensed under a Creative Commons Attribution 3.0 License. 